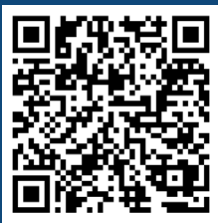

Keywords:

Development

Biodiversity

Sustainability

Policy

Received 16/05/2019 Accepted 01/10/2019

Correspondence:

birben@karatekin.edu.tr
Üstüner Birben ${ }^{1 \mathrm{a}+}$

\section{THE EFFECTIVENESS OF PROTECTED AREAS IN BIODIVERSITY CONSERVATION: THE CASE OF TURKEY}

BIRBEN, U. The effectiveness of Protected Areas in Biodiversity Conservation: The Case of Turkey. CERNE, v. 25, n. 4, p.424-438, 2019.

\section{HIGHLIGHTS}

Protected areas does not guarantee good governance of biodiversity.

Development concerns in developing countries can cause biodiversity loss.

Biodiversity conservation should be considered under the concept of "Over-riding public interest”.

Protected areas should be taken under constitutional protection when necessary.

\section{ABSTRACT}

The biodiversity on Earth, with the many species, ecosystems, and ecological processes that constitute the natural environment, is of incalculable value to humanity. Conservationists efforts are often inspired by Turkey's unique biological system, which is highlighted by a broad biodiversity and a $34 \%$ rate of endemism. This fragile biotic wealth is sometimes threatened by pressures for economic development. Biodiversityrich regions tend to have more urgent needs for conservation but frequently lack the financia resources and human capacity to achieve effective protections. Even so, there are many legislative leaders, institutional administrators, and other persons who are willing to work to save protected areas, or conservation areas (although this does not mean that their resource value would be properly protected); in fact, Turkey is one of the most enlightened nations in this regard. An institutional approach has been followed to bring new perspectives to the debate about the effectiveness of protected areas in Turkey. Protected areas have decreased steadily, from 5.647.568 ha in 2012 to $3.45 \mathrm{I} .947$ ha in 2018. This analysis confirms that protected areas face institutional restrictions, lapses in management, and capacity limitations. There is a need for a more adaptive approach to policy-making processes related to biodiversity conservation in Turkey. 


\section{INTRODUCTION}

Biodiversity supports societies in ecological, economic, cultural, and spiritual ways (MOF, 200I). Even though biodiversity has essential influences on daily social life and development, the world is facing bizarre and generally irrevocable biodiversity losses (Ervin et al., 2010). The types of species and systems and the threats they face are different in different geographical regions and within those regions (Myers et al., 2000). Two threats that are seen around the globe, however, are rapid urbanization and insufficient or weak land management policies (Huang et al., 2018). It is important to preserve high levels of diversity for many reasons, including all that the natural world contributes to human life (Rounsevell et al., 2018). Therefore, the conservation and protection of nature and the conservation of biodiversity have been seen as one and the same issue in recent years (Mathews, 2016).

There are many definitions of biodiversity (Jacobs et al., 20I3); one is "the diversity of life on Earth" (MEA, 2005). Biodiversity has been one of the most important conservation issues since the Convention on Biological Diversity (CBD) was signed in 1992 (Lu and $\mathrm{Qu}, 2018$ ). The CBD aimed to preserve the world's biodiversity for future generations (Eichner and Pethig, 2018) while ensuring viability rather than abundance for species populations (Piaggio et al., 2017). At the United Nations Conference on Sustainable Development (also known as Rio +20), leaders of the world restated and reemphasized the value of biodiversity, its vital role in supporting ecosystem services, and the importance of implementing actions to stop and reverse biodiversity losses (Bertzky et al., 20I2)._Scientists continue to look for ways to highlight the importance and value of biodiversity for society (De Groot et al., 2002; Pimentel et al., 1997; Wood, 1997).

In 2017, as described in Ripple et al. (2017), 15.364 scientists from 184 countries signed a "warning to humanity" and affirmed an exhaustive agenda for the protection of planet Earth (Chapron et al., 20I8). Their goal was to alert people to the fact that biodiversity loss changes ecosystem functions and services necessary for human well-being (FAO, 20I0). Species and habitats around the world are under increasing threats (Rice, 2018), mainly from entities that are pursuing economic gain (Tisdell, 20I I). Humans have changed ecosystems faster and more extensively in the last five decades than at any comparable time period in human history (MEA, 2005). Substantial developments can have significant effects on biodiversity (de Witt et al., 2019). Human activities having a negative impact on biodiversity have gained global attention and made the issue one of the core research topics in the 2 Ist century (Velasco et al., 2015); global biodiversity has declined (Hoffmann et al., 20I I; Tittensor et al., 20I4) at an "unprecedented" and "alarming" rate (Scholes and Biggs, 2005). Habitat destruction, the introduction of unwanted species into unfamiliar ecosystems, climate change, and pollution are current anthropogenic threats to biodiversity (Worm et al., 2003). In the literature, the interactions between land use and biodiversity have been extensively examined (Haines-Young, 2009; Sala et al., 2000). Land transformation is globally the main driver of biodiversity loss (Vitousek et al., 1997). Forty percent of the world's land is currently used for agriculture (Sanderson et al., 2002), and $75 \%$ is subject to quantifiable human coercion (Venter et al., 2016). Additionally, land used for a country's infrastructure, residences, and industrial facilities becomes transformed, leading to habitat destruction, fragmentation, ecosystem degradation, and, over time, species loss (Gibbons and Lindenmayer, 2007; Maron et al., 2010; Steffen et al., 2015). Despite efforts to halt biodiversity loss, these encroachments continue to cause a massive decline in biodiversity worldwide (Butchart et al., 20I0; Ceballos et al., 2015; Wetzel et al., 2018). These pressures are often concentrated in places rich in biodiversity (Hansen et al., 20 I3; Hassan et al., 2005). Evidence indicates that current conservation approaches and measures do not slow the overall rate of biodiversity loss; according to all indicators, we are losing this battle (Piaggio et al., 2017). We are in the middle of a "biodiversity crisis," and the loss of biodiversity continues to be considered one of the most urgent environmental problems in spite of global efforts to halt it (Gordon, 2006; Gustafsson, 2013).Long-standing debates about the unprecedented extinction rates of species increase the urgency for effective conservation management practices (Campbell et al., 2017). The conservation community is examining basic assumptions about the way conservation has been carried out (Sterling et al., 2017). Conservation planning has become ever more sophisticated and rigorous (Groves and Game, 2016). Thus, many conservation programmes have been presented to counter declines in biodiversity (Cullen et al., 200I). The formation of protected areas (PAs) is one of the main strategies and solutions for biodiversity conservation (Rodrigues et al., 2004); it is the predominant approach (Palacín and Alonso, 2018) for reducing habitat loss rates (Butchart et al., 2012), has become the indispensable core of conservation efforts, has had positive effects on biodiversity worldwide (Chape et al., 
2005; Gray et al., 2016), and has been widely regarded as a milestone by various researchers (Gaston et al., 2008). Such "command and control" approaches have been the basis of environmental policy for many years and have played an important role in the improvement and development of the environment (Rice, 20I8). All biodiversity partners should rely on specific legal and policy regulations. This is a particular manifestation of "path dependency," for example, an effort to protect a particular species or habitat mix in a PA (Burch et al., 20I4). In addition, the level of biodiversity protection in PAs may vary greatly (Costello and Ballantine, 20I5) due to different protection statuses and different priorities and objectives, as well.

The assessment of the institutional structure and legal arrangements related to biodiversity conservation is one of the tools that may lead to a better decisionmaking process and, therefore, to the development of biodiversity-related institutions that are highly effective and legislation that is highly enforceable for environmental policy and nature protection. This is most clearly seen when the dynamic interplay of institutions and conservation statutes is taken into account. Thus, the main aim of this study is to identify how weak legal frameworks and management efforts may lead to or play a critical role in the loss of biodiversity. This article emphasises that there is a dilemma between the status of a PA and the legislative framework related to biodiversity conservation. Having general information about what is at stake is very helpful in understanding the importance of the issue. Therefore, this analysis will begin primarily by presenting general information on the richness of biodiversity in Turkey.

\section{Biodiversity of Turkey}

The biodiversity of Turkey has been gaining attention because of its unique and invaluable nature. Turkey is situated at the nexus of Europe, the Middle East, Central Asia, and Africa (Şekercioğlu et al., 20 I I). It occupies a peninsula surrounded by the Black Sea, Aegean Sea, and Mediterranean Sea and has a land area of 783.562 $\mathrm{km}^{2}$ with a coastline of more than $8.000 \mathrm{~km}$ (Zeydanlı et al., 20I2). Its location takes advantage of different atmospheric circulation systems and their transitional zones. Its topography has a strong influence on both its climate and its vegetation. The topography of a country refers to its physical characteristics, whether natural or human-made, including all horizontal and vertical variations in its terrain. As the vegetation grows, it enhances various aspects of the topography. Certain topographical features such as mountains and rivers may serve as barriers to weather systems, which may affect air temperatures and amounts of precipitation (Şenkul and Doğan, 20 I3). Turkey has three biogeographical regions: the European-Siberian region, which encompasses the Black Sea coastline and circumambient mountains; the Mediterranean region, which encompasses the Mediterranean coast and mountains; and the Irano-Turanian region, which encompasses the Central East and Southeastern Anatolia regions (Gökyiğit, 20I3; MOF, 1998). These areas have very different ecosystems (coastal, marine, mountainous, forested, steppe, wetland, agricultural) (Şimşek, 2014). The ecosystems have enormous numbers of plant and animal species some of which have large populations and many of which are endemic (MOE, 200I). Past geological and climatic processes (Zeydanlı et al., 20I2) have made Turkey the region's richest country in terms of biodiversity. Steppe ecosystems in Central and Eastern Anatolia may be the most important of all in economic terms because many food crops are derived from wild species native to Turkey (MOE, 200I).

Biodiversity hotspots are areas with extraordinary concentrations of species at an exceptional level of endemism that are facing especially formidable threats (Myers, 1988). These hotspots cover $2.3 \%$ of the total land area of the world and contain $50 \%$ of all endemic plants in the world (Satar and Güneş, 20I4). Turkey has 3 out of the 36 biodiversity hotspots on Earth: the Mediterranean, Caucasus, and Irano-Anatolian hotspots (Figure I) (AFD, 2016; CEPF, 2019).

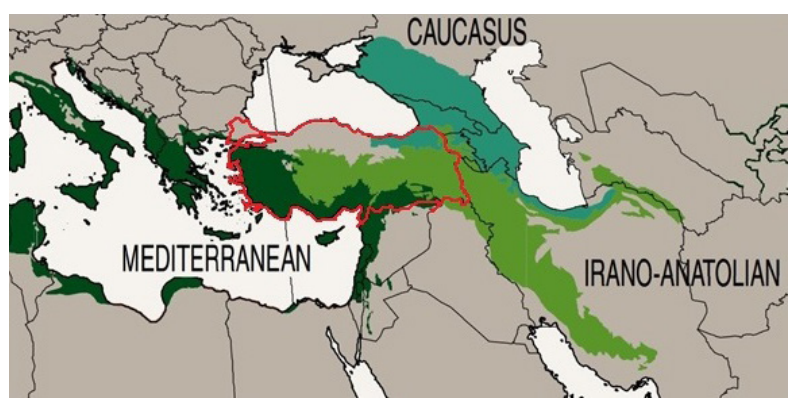

FIGURE I Biodiversity hotspots in Turkey (adapted from (Mittermeier et al., 2005).

Stakeholders around the globe have acknowledged the significance of forests for biodiversity and have focused on the conservation of their biodiversity and ecosystem functions (Morales-Hidalgo, 20I5). Forestlands cover almost $30 \%$ of the Earth's land surface (Keenan et al., 20I5) and contain more than $50 \%$ of the world's known or identified terrestrial plant and animal species (Aerts and Honnay, 20II; Miller and Spoolman, 2015; Thompson et al., 2009; WWF, 20I5), yet only $8 \%$ of the 
world's forests are officially designated as PAs (Schmitt et al., 2009). Turkey has roughly 23 million ha of forested areas (29\% of the country's total land area) of which 12,9 million ha is productive and 2,4 million ha is certified by the Forest Stewardship Council (FSC) (GDF, 2018). Turkey's forest ecosystems have more than 40 economically important tree species with a natural distribution (MOE, 200I). The International Cooperative Programme on Assessment and Monitoring of Air Pollution Effects on Forests (ICP Forests) is a transnational monitoring and research network established under the United Nations Economic Commission for Europe (UNECE) Air Convention in 1985. Forty-two countries are currently cooperating in the ICP Forests organization (Michel et al., 2018); Turkey has been a long-time member of the programme (Tolunay et al., 20I2). When the ecological features (Atalay et al., 2014) and biogeographical regions of Turkey's forests are considered, they can be classified as shown in Table I.

The richness of the forest ecosystems in Turkey provides numerous endemic plant, rare bird, and wildlife species. These ecosystems include the wild "relatives" of many cultivated plants that are important for agricultural biodiversity. In fact, more than $60 \%$ of the land surface of Turkey is used for agricultural biodiversity fundamentals (MFWA, 20I4). The world's largest remaining forests of cypress and Lebanon cedar trees are in the Caucasus Mountains and Mediterranean region of Turkey. With regard to the importance of the existent fauna in Turkey, two of the globally threatened animal species in Europe, the black vulture and imperial eagle, are breeding in the forests of Turkey (MOE, 200I). Thus, Turkey has extensive natural forests and is host to nine globally important forest ecosystem hotspots (Çağatay et al., 20I3). Figure 2 shows the forest cover of the country and its nine forest ecosystem hotspots: the Karçal Mountains, Fırtına Valley, Küre Mountains, Yenice Forests, İstanbul Forests, Datça and Bozburun Peninsulas, Fethiye Babadağ, ỉbradiAkseki Forests, and Amanos Mountains.

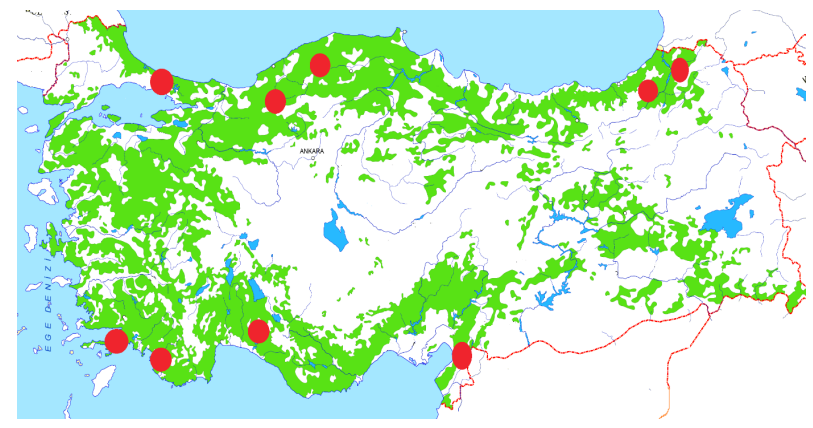

FIGURE 2 Forest cover and the nine forest ecosystem hotspots in Turkey (adapted from (Saygill, 2016; Şekercioğlu et al., 20I I).

In 122 countries, there are 686 biosphere reserves, including 20 cross-border ones (UNESCO, 2019). The Camili Biosphere Reserve in Turkey is the first one to be designated as an ecological and cultural sanctuary. It is in the Karçal Mountains, far from the impact of human civilisation (Ertürk, 2019). Turkey's four seas have distinct ecological characteristics and the highest biological diversity in the Mediterranean region. Roughly 3000 species have been identified and recorded in them (MOF, 1998). The distribution of fish species in the seas are as follows: the Black Sea, I5I; the Marmara Sea, 249; the Aegean Sea, 389; and the Mediterranean Sea, 388 (MFWA, 2014). There are no endemic and endangered species among the marine fishes, but of the 236 inland water species, 70 are endemic and 4 are extinct (MEF, 2009). Wetlands have the most biodiversity after tropical forests in terms of feeding, breeding, and hosting of many species (MOEF, 2007). Turkey has more than 1,2 million ha of wetlands; however, over 200 thousand ha of wetlands have been lost. Because, they have been drained to become dry land since the 1960s. Wetlands are habitats for numerous water birds and different aquatic species. There are nearly 250 wetlands in Turkey, many of which are of international importance. Turkey's wetlands are vital for migrating bird species because of

TABLE I Forest types in Turkey by biogeographical region (MEF, 2009).

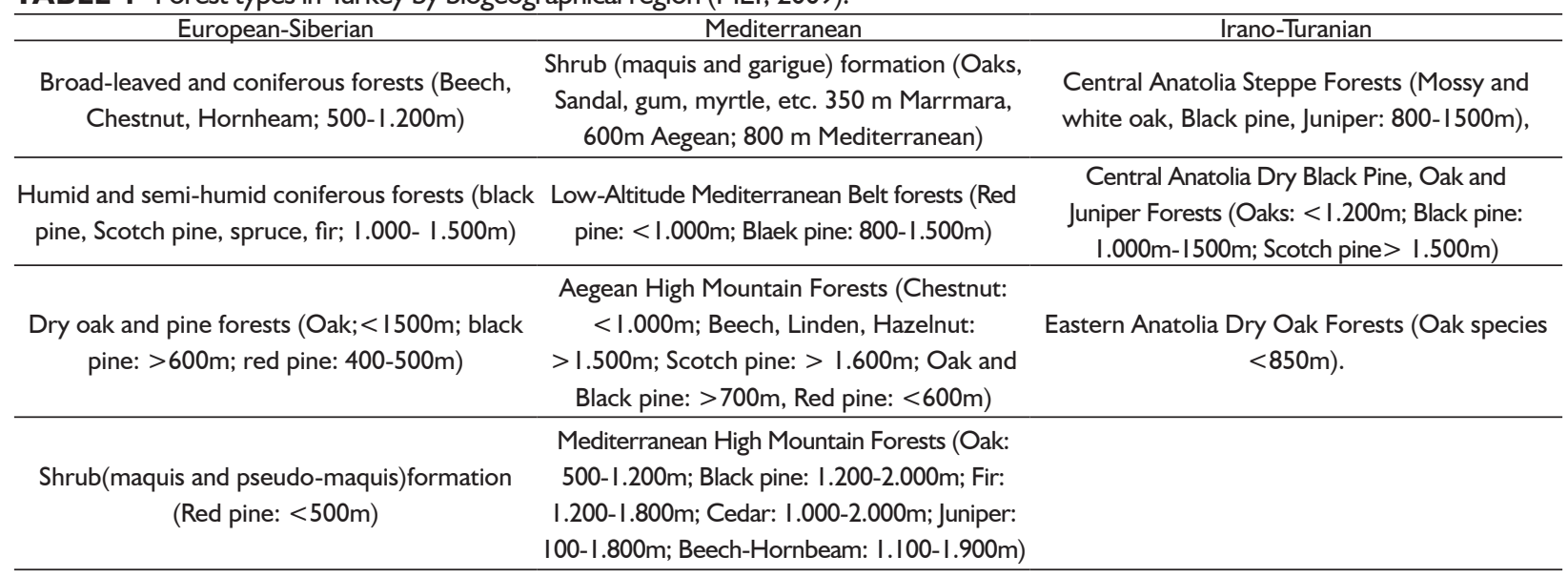


the country's geographical location. Therefore, wetlands in Turkey have far greater importance than those of many other countries because they provide important habitats for shelter and feeding and enable the birds to migrate over long routes safely (MOE, 200I). The common otter, seen in most of Turkey's wetlands, is under the threat of extinction and is protected all over Europe. The endemic darter, subspecies Anhinga melanogaster rufa, became extinct when Amik Lake was drained and became dry land to be used for agricultural purposes (MOEF, 2008).

Of the I,7 million plant and animal species that have been identified on Earth, Turkey is host to approximately 76.539 of them (Çağatay et al., 20I3). There are about I2.000 plant species in all of Europe (MOEF, 20 I I; Şimşek, 20I4; Üstündağ, 20I5), and $75 \%$ of them can be seen in Turkey (Can, 2013; Tan, 20l0; Terzioğlu et al., 2012; Terzioğlu et al., 20I5; WorldBank, 200I). This percentage is more than twice as high as in surrounding countries (MOE, 200I). The northern part of the Fertile Crescent, where agriculture was developed more than 10.000 years ago, is in Turkey (Gross, 2012). Its presence can be attributed to geographical variations that foster a high level of genetic diversity and endemism (Demirayak, 2002) for many significant edible and agricultural plant species (Atik et al., 2010; Avcı, 2005). Turkey has five microgene centers: the Thrace-Aegean region; Southern and Southeastern Anatolia; the Samsun-Tokat-Amasya region; Kayseri and its environs; and Ağrı and its environs (Harlan, 195I), Turkey offers vital genetic diversity resources that provide sustainability for many horticultural plants on a global scale (IUCN, 20I2). Over 12.006 plant taxa, 3925 of which are endemics, can be found in Turkey (Erik and Tarıkahya, 2004; MFWA, 20I4), and among continental countries, Turkey is ranked as ninth in terms of biodiversity richness, with a rate of over $33 \%$ for floristic endemism (MOE, 200I). A new plant species is identified or recorded every 10 days in Turkey (Güner, 2016). When considering Turkey's $780.080 \mathrm{~km}^{2}$ of land area, it was determined that the arithmetic density ratio of the endemic plant taxa is 1.24 per $100 \mathrm{~km}^{2}$ (Şenkul and Kaya, 20I7).

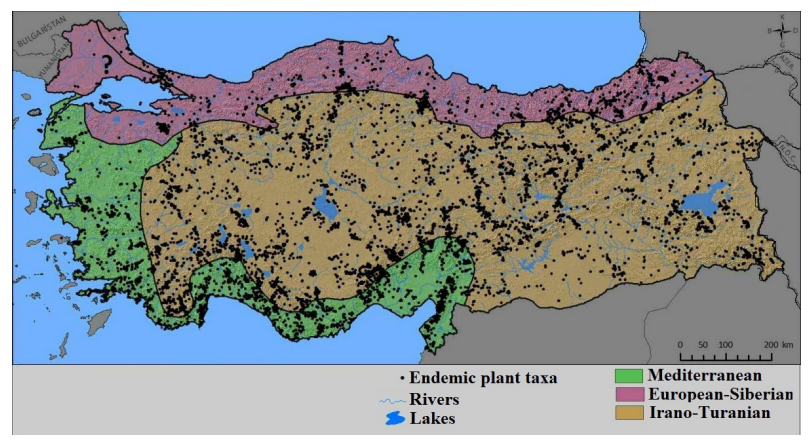

FIGURE 3 The 9677 locations in Turkey in which 2900 endemic taxa are found, shown by biogeographical region (Şenkul and Kaya, 20I7).
The endemism ratio of $34 \%$ is higher than in other European countries, such as Greece (14.9\%), France (2.9\%), Spain (18.6\%), or Poland (0.1\%) (Avcl, 2005) (MFWA, 20l4). Among the countries in the temperate zone, Turkey has the richest flora, with roughly 10.000 vascular plant and fern species. Unfortunately, according to the International Union for Conservation of Nature (IUCN) Red List Categories, approximately 1.000 endemic plant species of the grassland and Mediterranean ecosystems are threatened (DoğaDerneği, 2019). Approximately I.890 plant species are specific to geographical regions of Turkey, and I.200 of them are found in more than one geographical region. The Mediterranean and Central and Eastern Anatolia regions have the most endemic plant species (Atik et al., 2010; Médail and Baumel, 2018); they are often found in mountainous areas, such as the Taurus Mountains (the most by far), Amanus Mountains, and Mount Ida, and in the Salt Lake region (Karagöz, 2003). Table 2 shows endemic plant species (including subspecies and varieties) in the various phytogeographical regions in Turkey.

TABLE 2 Endemic plants in the phytogeographical regions of Turkey (MFWA, 20I4)).

\begin{tabular}{cc}
\hline European-Siberian & 320 \\
\hline Mediterranean & 1.325 \\
\hline Irano-Turanian & 1.250 \\
\hline Non-specific & 1.030 \\
\hline Total & 3.925 \\
\hline
\end{tabular}

Turkey possesses a significant diversity of animal species, much like its floral richness, with over 80.000 species (MOE, 200I). There are nearly 19.000 invertebrate species, and 4.000 species or subspecies of these are endemic (Çağatay et al., 2013). The fauna of Turkey include I6I types of mammals, 469 of birds, I4 I of reptiles, 18 of frogs, 480 of saltwater fish, and 236 of freshwater fish. Of vertebrates, there are nearly 1500 species, and over 100 of them are endemic (70 of the 100 are fishes). It is estimated that there are 60.000 to 80.000 species of insects in Turkey (MEF, 2009; MOEF, 20I I; Şimşek, 20I4; Üstündağ, 20I5). The faunistic lists of some insect groups are nearly complete, showing that there are II 4 types of dragonflies, 522 of mollusks (and 203 of them are endemic), 600 of locusts (and 270 of them are endemic), 10.000 of beetles, 1.400 of bugs, I.500 of plantlice, and 6.500 of butterflies (600 of them are diurnal and the rest are nocturnal) (MFWA, 2014).

Besides being the homeland of pheasants and fallow deer, the coastal areas of the Mediterranean Sea and Aegean Sea in Turkey provide shelter and refuge for the endangered Mediterranean monk seal, loggerhead sea turtle, and green turtle (MOF, 200I). 
Turkey is on the three main migratory bird routes in Europe, as well (MOEF, 2007), and two of them are in the vital West Palaearctic region (Figure 4) (MOF, 200I).

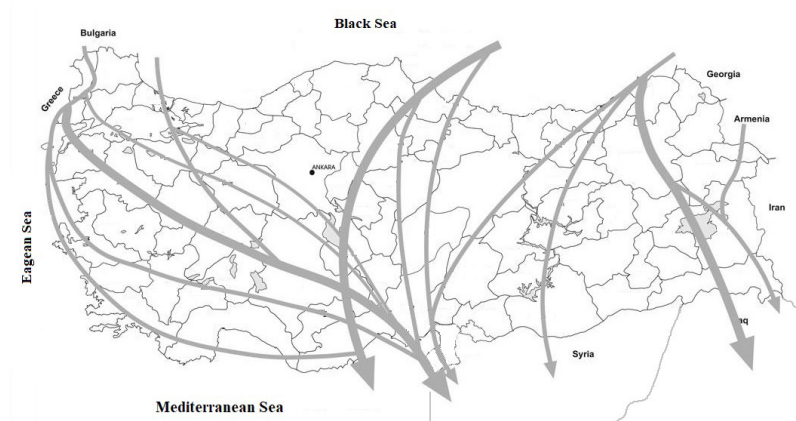

FIGURE 4 Main bird migration routes in Turkey (adapted from (Hacıoğlu et al., 2017).

Of the 23 bird species that are endangered in Europe, 14 can be seen in Turkey. The corn Audoin's gull, white-headed duck, Dalmatian pelican, marbled teal, and ferruginous duck, which are also endangered and protected, nest in Turkey. More than $60 \%$ of the world's white-headed duck population stays in Turkey during the winter season (MOF, 1998). Turkey is home to 313 ant species (Karaman and Aktaç, 2013; Karaman et al., 2015; Kiran and Karaman, 20I2) and 38I species of butterflies of which 45 are endemic (Karaçetin and Welch, 20I I). In all of Europe, there are 482 species of butterflies (Van Swaay et al., 2010), and Europe has 65 prime butterfly areas (Zeydanlı et al., 20I2).

The number of studies on algae carried out by researchers has increased in Turkey, but the inventory of the country's algal flora is not yet complete. The identified lichen species in the world are around 20.000. Studies on lichens in Turkey have increased rapidly in recent years. Nearly I.000 species have been identified, and the count is continuing (MFWA, 2014). There are also nearly 1.030 bryophyte species: 835 of mosses (7 of them are endemic), 191 of liverworts ( 3 of them are endemic), and 4 hornworts (Ursavaş and Işın, 20I8).

\section{Protected Areas in Turkey}

For more than a century, the designation of PAs has been a central strategy to preserve biodiversity. It is well known that well-managed PAs not only assist healthy ecosystems and species under threat, but they also provide many benefits for people (Bertzky et al., 20I2); without them, the loss of global biodiversity would be even greater and more inevitable than it already is. The PAs are at the center of multiple-party, international policy efforts, including the RAMSAR Convention on Wetlands of International Importance, especially as Waterfowl Habitat; the 2030 Agenda for Sustainable Development; and the Convention on Biological Diversity (CBD) (UNEP-
WCMC et al., 20/8). These are the most substantial environmental and sustainable development commitments that governments have made so far in the international arena. They have acknowledged the core role of PAs in the sustainable development and preservation of biodiversity. PAs are also stressed in the Sustainable Development Goals of the Rio+20. Two of the goals are related especially to biodiversity: Goal 14 focuses on coastal and ocean ecosystems, and Goal 15 focuses on terrestrial ecosystems, forests, and desert ecosystems. The Aichi Biodiversity Target II also highlights PAs in conservation efforts (UNEP-WCMC and IUCN, 2016).

The designation and maintenance of PAs is the backbone of global biodiversity conservation strategies to end losses. Despite the fact that 234.468 PAs have already been established worldwide, their effectiveness in protecting biodiversity is in question because the extinction rates of species have not declined to the desired level (GuadillaSáez et al., 2019; UNEP-WCMC and IUCN, 20I7). The site designation rate is underlined as one of the most noteworthy conservation achievements of the 20th century (Gaston et al., 2008). As efforts continue in this direction, there are hopes that a target of $17 \%$ coverage for terrestrial regions and inland waters can be achieved by 2020 , in the context of Aichi Biodiversity Goal II (Gannon et al., 20I7).

Turkey has been facing some constraints in achieving the CBD targets, even though it has been a party to the Convention since 1996 and has been pursuing PAs for more than 60 years (Dudley et al., 2005). A significant amount of Turkey's rich plant and animal biodiversity is in danger. This is not due to the lack of viable PAs. There are 15 categories of PAs in Turkey as a result of national and international interests in conserving biodiversity and natural resources; they are shown in Table 3.

According to the United Nations Environment Programme World Conservation Monitoring Centre (UNEP-WCMC) data of 2018, the ratio of world terrestrial and marine PAs to the total terrestrial area has increased from $11.90 \%$ in 2000 to $14.94 \%$ in 2018 and the total number of PAs is 236.193 in 145 countries and territories. PAs have been designated in countries such as South Africa (terrestrial $8 \%$, marine 12\%); China (terrestrial 16\%, marine 5\%); India (terrestrial 6\%, marine 0\%); Japan (terrestrial 29\%, marine $8 \%$ ); France (terrestrial 26\%, marine 45\%); Germany (terrestrial $38 \%$, marine $45 \%$ ); Russian Federation (terrestrial $10 \%$, marine 3\%); Canada (terrestrial 10\%, marine $3 \%$ ); and the United States (terrestrial 13\%, marine 42\%) (ProtectedPlanet, 2019). In Turkey, the share of PAs was $10.10 \%$ in 2013 ; it decreased to $8.50 \%$ in 2014 , increased to $8.90 \%$ in 2015 , increased further to $9.10 \%$ in 2016 , and was estimated as $8.90 \%$ in 2018 . 
TABLE 3 PA categories in Turkey (GDNCNP, 2016, 2019; MOEU, 2019).

\begin{tabular}{|c|c|c|c|c|c|c|}
\hline Years & \multicolumn{2}{|c|}{2013} & \multicolumn{2}{|c|}{2016} & \multicolumn{2}{|c|}{2018} \\
\hline PAs under Ministry of Agriculture and Forestry & Quantity & Area (ha) & Quantity & Area (ha) & Quantity & Area (ha) \\
\hline National Parks & 40 & 848.119 & 42 & 845.814 & 43 & 845.814 \\
\hline Nature Parks & 189 & 89.832 & 209 & 99.378 & 229 & 102.505 \\
\hline Nature Monuments & 112 & 6.678 & 111 & 7.142 & 111 & 7.206 \\
\hline $\begin{array}{l}\text { Nature Conservation Areas } \\
\text { Wildlife Enhancement Areas }\end{array}$ & $\begin{array}{l}31 \\
80\end{array}$ & $\begin{array}{l}63.694 \\
1.191 .340\end{array}$ & $\begin{array}{l}30 \\
81\end{array}$ & $\begin{array}{c}47.244 \\
1.189 .293\end{array}$ & $\begin{array}{l}30 \\
81\end{array}$ & $\begin{array}{l}64.224 \\
\text { I.I92.794 }\end{array}$ \\
\hline Wetlands(Locally Important areas) (I) & & & 6 & 1.602 & 6 & 1.602 \\
\hline Wetlands (Nationally Important areas) (I) & 121 & I.735.495 & 38 & 469.830 & 20 & 278.072 \\
\hline Wetlands (RAMSAR areas) & 14 & I84.487 & 14 & 184.487 & 14 & 184.487 \\
\hline Protection Forests & 55 & 251.409 & 55 & 251.548 & 55 & 250.033 \\
\hline Gene Conservation Forests (in-situ) & 258 & 37.098 & 295 & 39.732 & 283 & 38.828 \\
\hline Seed Stands (in-situ) & 347 & 46.106 & 330 & 43.858 & 337 & 44.664 \\
\hline Seed Orchard (ex-situ) & 179 & 1.313 & 187 & 1.442 & 184 & 1.421 \\
\hline Urban Forests & 126 & 11.867 & 145 & 10.550 & 133 & 10.315 \\
\hline Total Overlapping & 1.552 & 4.467 .438 & 1.543 & 3.191 .920 & 1.526 & 3.021 .965 \\
\hline & $5.48 \%$ & & $3.91 \%$ & & $3.70 \%$ & \\
\hline PAs under the Ministry of Environment and Urbanization & Quantity & Area (ha) & Quantity & Area (ha) & Quantity & Area (ha) \\
\hline Special Environmental Protection Areas & 16 & 2.459 .116 & 16 & 2.458 .749 & 16 & 2.460 .041 \\
\hline Natural Sites & 1.273 & I.322.749 & 2.430 & 1.773 .856 & 2.430 & I.773.856 \\
\hline Total Overlapping & 1.289 & 3.781 .865 & 2.446 & 4.232 .605 & 2.446 & 4.233 .897 \\
\hline General Total Overlapping & $2.84 \mathrm{I}$ & 8.249 .303 & 3.989 & 7.424 .525 & 3.972 & 7.255 .862 \\
\hline PAs ( $\%$ of total land area) & & $10,10 \%$ & & $9,10 \%$ & & $8,90 \%$ \\
\hline
\end{tabular}

The main reason for the decline was the adoption of the registration process for wetlands in the amendment to the wetlands regulations in 2014 (MOEU, 2019). The number of PAs that are under the management of the MOAF has decreased quite steadily (from 5.647.568 ha in 2012 to 3.451 .947 ha in 20I8), with the exception of some gains in 2015, as shown in Figure 5 and Figure 6.

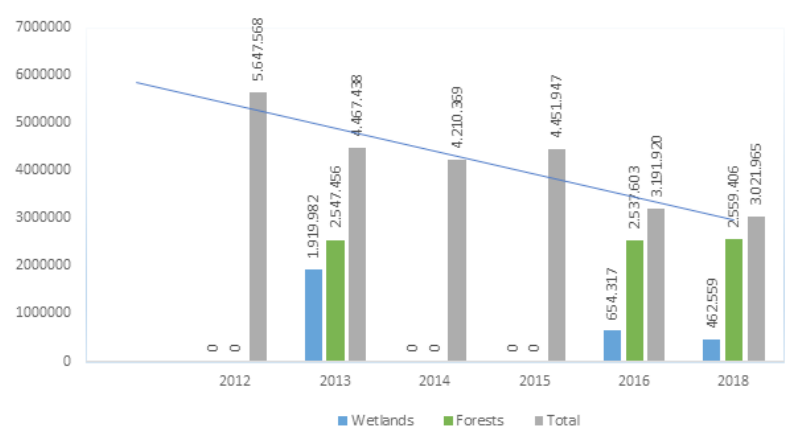

FIGURE 5 Changes in the areal extent of protected areas (GDNCNP, 2013, 2016, 2019; MOEU, 2019).
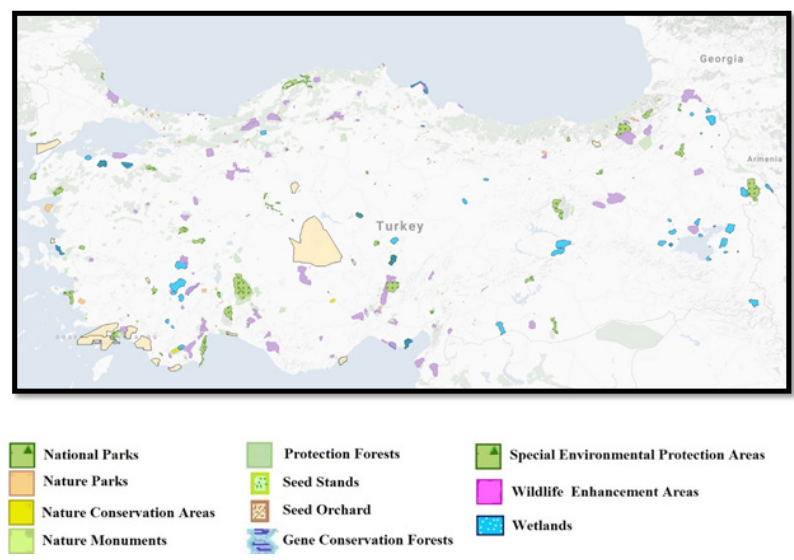

FIGURE 6 Protected areas in Turkey (MOAF, 20I9).
Most of the terrestrial PAs are state-owned forest areas. They and the marine PAs are the responsibility of the MOAF and the Ministry of Environment and Urbanisation and its affiliated General Directorate for Protection of Natural Assets. The legal framework related to the PAs is mainly based on different legislative and regulatory tools. The main tool set includes constitutional provisions, laws, decree laws, and regulations and also many important international conventions, protocols, and treaties (Table 4) (Erdönmez et al., 2010).

TABLE 4 International conventions, protocols, and treaties related to biodiversity in Turkey.

RAMSAR Convention I97|
World Heritage Convention I972
CITES- I973
Bern Convention I979
UN Convention on Biological Diversity (CBD) I992
UN Framework Convention on Climate Change I992
UN Convention to Combat Desertification I 994
European Landscape Convention 2000
International Treaty on Plant Genetic Resources for Food and
Agriculture 2004
Cartagena Protocol on Biosafety 2004
Kyoto Protocol 2009

There are also 35 laws, 3 decree laws, 23 regulations, and 10 circulars dealing with environmental issues, many of them directly or indirectly related to biodiversity (MOF, 1998). The National Parks Law No. 2873 is the core legislation for the PAs, and it is supplemented by the Environment Law of 1983, Land Hunting Law of 2003, Forest Law of 1956, and Law on Protection of Cultural and Natural Assets of 1983. All are in place for the express purpose of promoting biodiversity and vulnerable ecosystem conservation. Table 5 shows the main policy tools for PAs. 
TABLE 5 Main policy tools for protected areas in Turkey.

\begin{tabular}{cl}
\hline $\begin{array}{c}\text { Main Policy } \\
\text { Tool }\end{array}$ & \\
\hline & 10. Development Plan (20I4/2018) \\
9. Development Plan (2007/20I3) \\
Development & 8. Development Plan (200I-2005) \\
Plans & 7. Development Plan (1996-2000) \\
& 6. Development Plan (1990-1994) \\
& 5. Development Plan (1985-1989)
\end{tabular}

National Strategy and Action Plan to Combat Desertification (2015/2023)

Turkey's Climate Change Action Plan (201 I/2023)

National Capacity Action Plan (20II)

National Environmental Action Plan (1998)

National Environmental Strategy and Action Plan (1999)

National Environmental Strategy and Action Plan of Turkey (1998)

National Biodiversity Strategy and Action Plan of Turkey (1999)

Action Plans National Biological diversity Strategy and Action Plan (200I)

National Plan for In-Situ Conservation of Plant Genetic Diversity (1998)

National Plan on In-Situ Conservation of Plant Genetic

$$
\text { Diversity in Turkey (1997) }
$$

National Plan for In-situ Conservation of Plant Genetic Diversity in Turkey (1996)

Mediterranean Action Plan (2002)

National Forestry Program (2004/2023)

Turkey's Public Environment and Forestry Research Program (2006)

Water Projects (Ecosystem Approach, Basin Management,

Biological Monitoring) National Park, Wetland, Wildlife, Hunting Projects

National Biodiversity Inventory and Monitoring Project

Basin and Landscape Projects (Basin and Landscape) The Combating Biopiracy Project (2013-20I5) Regional

Development Projects (2015/2019)

Projects/ Programs

In-situ Conservation of Genetic Diversity (GEF I) Biological Diversity and Natural Resource Management (GEF II)

The Black Sea Environment Project (GEF-BSEP)

Belek Coastal Administration Plan Project

Protection of the Mediterranean Monk Seal in Turkey- Foça and Yalıkavak Pilot Projects

National Agenda 2 I Programme (200I)

Turkey Climate Change Strategy (2010-2023)

National Environmental Strategy and Action Plan (1997)

National Environment Strategy and Action Plan (1998)

National Biodiversity Strategy and Action Plan of Turkey (1999)

Strategy National Biodiversity Strategy and Action Plan (200I)

Documents The National Strategy and Action Plan for Biodiversity in Turkey (200I)

National Wetland Strategy (2003-2008)

National Biological Diversity Strategy and Action Plan (2007)

General Directorate of Forestry Strategic Plans (2010-20I4 / 2013-2017 / 2017-2021)

\begin{tabular}{cc}
\hline $\begin{array}{c}\text { Council } \\
\text { Reports }\end{array}$ & Forest and Water Final Reports (2013 / 2017) \\
\hline Master Plans & $\begin{array}{c}\text { National Forestry Research Master Plan 2007-20I2 } \\
\text { Forestry Research and Development Master Plan 2016-20I7 }\end{array}$ \\
\hline $\begin{array}{c}\text { Government } \\
\text { Programs }\end{array}$ & Government Programs (1989-20I7) \\
\hline
\end{tabular}

\section{DISCUSSION}

Natural resource exploitation, pollution, and the invasions of alien species into unfamiliar territory have led to a significant decrease in biodiversity and ecosystem services, and they are likely to continue to pose serious threats, especially as climate change continues (Rounsevell et al., 2018). Biodiversity-rich regions tend to have more protection needs but often lack the financial resources and human and institutional capacities to provide effective protection (Campos-Arceiz et al., 2018). This is more remarkable in the case of Turkey. Because, biodiversity richness represented by Turkey (ranked as ninth) alone is almost equivalent to the level of the European continent represented by. Moreover, 34\% of endemism rate, the vital genetic diversity resources for commercial agriculture, the wild "relatives" of many cultivated plants, and the nine globally important forest ecosystem hotspots are further increasing this importance. The fact that the forestlands representing approximately $\mathrm{I} / 4$ of the country surface area is under State control/ownership shows both an advantage and a disadvantage in terms of PAs status. The advantage is that the State itself is responsible for the protection and development of forests and the State's resources can be utilized in terms of both financial and human resources. It is also disadvantage because the state authority has the ability to make changes to the protected area statuses and can determine the scope, duration and application forms of the permits to be granted in these areas. Moreover, there is no legal obstacle to mining activities which have undeniable damages on the PAs. In fact, the president of republic of Turkey may grant research and operation licenses or privileges in these areas designated under the National Parks Law. Increasing demand for mining activities will continue to be one of the major risk factors for protected areas in the future.

Turkish leaders are very familiar with the sustainable development approach and have been implementing it as the main environmental policy of the country. In fact, this particular policy has been at the forefront since 1937. One can see, however, that economic development and its imminent effects of rapid population growth, urbanization, and different consumption patterns and habits (Ünal et al., 2019) are threats to biodiversity (Coşkun, 2005). Besides being a biological "crossroads" between three continents with its important topographical and geomorphological features (Ergüner et al., 20I8), as a European country, Turkey not gets enough attention from the international community regarding its biodiversity to seek funding and 
set priorities for supporting protection (Şekercioğlu et al., 20II). Although much research has been done on Turkey's biodiversity, the true value and richness of it has not been fully determined and described as yet (Birben and Gençay, 2019). In emphasizing the richness of their biodiversity, ecosystems should be considered at the level of species, genes, and biological functions and evaluated in terms of their importance for sustainable agriculture, forestry, and industry (MEF, 2009).

In a dramatically changing world, when conservationists are faced with many developmental issues, PAs of different sizes, shapes, and governance systems are topics that will increase in importance in coming years (Juffe-Bignoli et al., 20l4). To ensure a more sustainable future for humankind and the planet, there is a need for more recognition of the vital role that PAs play in promoting sustainable development (UNEPWCMC and IUCN, 20I6).

A poor or incomplete understanding of the possible consequences of conservation objectives, interactions among targets, and actions necessary to achieve goals may lead to unusual, poor, or weak protection results, inefficient actions, and lost chances for fulfilling commitments (Nicholson et al., 2019). In the last decade, many important changes have occurred in Turkey's legislative proposals, administrative approaches, and policy implementations to enable developmental objectives for PAs (Atmiş, 2018). Yet, the share of PAs has decreased to $8.90 \%$ in 2018 from $10.10 \%$ in 2013 in spite of the absence of a significant lack of legislation ( 35 laws, 3 decree laws, 23 regulations, and 10 circulars), policy tools ( 6 development plans, 12 action plans, 14 projects/programs, 9 strategy documents, I council reports, 2 master plans, government programs), and the administrative and organizational structure. In addition to that, while trying to fulfill the commitments arising from international conventions and processes (the $C B D$, the Rio + 20, the 2030 Agenda for Sustainable Development, The Aichi Biodiversity Targets etc.), the fact that the protected areas are decreasing expresses a great contradiction for Turkey.

Integration of biodiversity into forest management plans is considered one of the basic strategies (GDF, 2016) in Turkey. Reasonably, MOAF's projects in the present are serving both the Aichi and the United Nations Millennium Development Goals (MFWA, 20I4). To reach that target, increased allocations of state-owned forest areas for "ecological functions" are being made. The national forestry programme led the three core functions for the state forests (i.e., the economic, ecological, and sociocultural functions), so as to achieve ecosystembased functional planning (GDF, 20I5). It is good that forest areas allocated for "ecological functions" rose from 6.912 .420 ha (32\%) in 2012 to 9.287 .840 (42\%) in 20I5. In the coming years, the number of PAs in Turkey is likely to increase and the process of adaptation to the European Union will play a significant role in this process (Yıldırım and Yurdakul Erol, 2012).

It is also very promising that a new institutional structure, the General Directorate of Nature Conservation and National Parks, has been established. The previous Section of Biodiversity and Genetic Resources has been retitled the Department of Biodiversity and has five divisions: research, inventory, monitoring, biotechnology, and information systems (MFWA, 20I4).

\section{CONCLUSION}

The loss of biodiversity is undeniably important, especially in areas with the richness of Turkey. Such losses can cause irreversible results for ecosystems and for human well-being. Biodiversity-rich countries with a low management capacity need short-term and long-term strategies for conservation, international aid and support, and development to improve their governance capacity (Huang et al., 2018). One can see, however, that international pressures on the inclusion of environmental approaches in legislative mechanisms have led to the rapid implementation of complex concepts without supporting legal enforcement mechanisms, institutional commitments or tasks, or conscious support opportunities. The fact that national legislation does not comply with international regulations (protocols, conventions, and treaties) causes contradictions in practice because it does not support implementation (MOF, 200I). The numerous legislation concerning the PAs and the frequent changes in this legislation represent a major problem in terms of implementation integrity as well. The PAs are still facing numerous problems in the sense of good governance in Turkey. But, improving the legal/political arrangements in the light of international agreements/conventions/ protocols to achive institutional/political/legal optimization is becoming increasingly important for the PAs. Because, it is very clear that the areas designated as PAs due to the international conventions, protocols, and agreements have not changed quantitatively in a negative way. On the contrary, there are significant terrestrial coverage and quantity increases over time.

The Draft Law on the Protection of Nature and Biological Diversity, which has been on the parliamentary agenda since 2012, might play a vital role in solving the challenges and issues by eliminating the problems related 
to legislation and institutions and might provide effective protection for biodiversity in Turkey. The National Biological Diversity Inventory and Monitoring Project was started in 2013 and is ongoing. The inventory has been completed in 54 provinces up to the present and is expected to be completed in the others by the end of 2019 (Birben and Gençay, 2019).

While conducting international law-based practices, the whole and rather complex the PAs related institutional settings/characteristics has to be reconsidered to ensure/harmonize diverse interests of the public. The command and control approach in Turkey is inadequate as the public perception of biodiversity has increased over the last few decades. The society is now able to demand the protection and development of these resources rather via NGOs or individually from the central authority. Public participation in the processes of policy and legislative development might also bolster the national framework for PAs in Turkey. Nevertheless, the attitude of the Ministry of Agriculture and Forestry towards public participation is positive and noteworthy.

Both the Turkey's active participants in FOREST EUROPE process and projects currently developed for NATURA 2000 network are very important. The meaningful gains from these processes and projects will have widespread/significant outputs for more coherent legislation and also for the development and improvement of the PAs management in Turkey.

\section{REFERENCES}

AERTS, R., HONNAY, O., 20I I. Forest restoration, biodiversity and ecosystem functioning. BMC Ecology II, 29.

AFD, 2016. Performing a Review of the Natural Resources and Biodiversity Sector in Turkey. French Development Agency, p. 98.

ATALAY, I., EFE, R., ÖZTÜRK, M., 20I4. Ecology and Classification of Forests in Turkey. Procedia - Social and Behavioral Sciences I20, 788-805.

ATIK, A.D., ÖZTEKIN, M., ERKOÇ, F., 20I0. Biyoçeşitlilik ve Türkiye'deki Endemik Bitkilere Örnekler. Gazi Üniversitesi Gazi Ĕgitim Fakültesi Dergisi 30, 219-240.

ATMIŞ, E., 2018. A critical review of the (potentially) negative impacts of current protected area policies on the nature conservation of forests in Turkey. Land Use Policy 70, 675-684.

AVCI, M., 2005. Çeşitlilik ve Endemizm Açısından Türkiye'nin Bitki Örtüsü. İstanbul Üniversitesi Edebiyat Fakültesi Coğrafya Bölümü Coğrafya Dergisi I3, 27-55.

BERTZKY, B., CORRIGAN, C., KEMSEY, J., KENNEY, S., RAVILIOUS, C., BESANÇON, C., BURGESS, N., 2012. Protected Plant Report 2012: Tracking progress towards global targets for protected areas. United Nations Environment Programme World Conservation Monitoring Centre, Cambridge, UK, p. 68.
BIRBEN, Ü., GENÇAY, G., 2019. Bio-smuggling in Turkey. Crime, Law and Social Change, 7I, 345-364.

BURCH, S., BERRY, P., SANDERS, M., 20I4. Embedding climate change adaptation in biodiversity conservation: A case study of England. Environmental Science \& Policy 37, 79-90.

BUTCHART, S.H.M., SCHARLEMANN, J.P.W., EVANS, M.I., QUADER, S., ARICÒ, S., ARINAITWE, J., BALMAN, M., BENNUN, L.A., BERTZKY, B., BESANÇON, C., BOUCHER, T.M., BROOKS, T.M., BURFIELD, I.J., BURGESS, N.D., CHAN, S., CLAY, R.P., CROSBY, M.J., DAVIDSON, N.C., DE SILVA, N., DEVENISH, C., DUTSON, G.C.L., FERNÁNDEZ, D.F.D.Z., FISHPOOL, L.D.C., FITZGERALD, C., FOSTER, M., HEATH, M.F., HOCKINGS, M., HOFFMANN, M., KNOX, D., LARSEN, F.W., LAMOREUX, J.F., LOUCKS, C., MAY, I., MILLETT, J., MOLLOY, D., MORLING, P., PARR, M., RICKETTS, T.H., SEDDON, N., SKOLNIK, B., STUART, S.N., UPGREN, A., WOODLEY, S., 2012. Protecting Important Sites for Biodiversity Contributes to Meeting Global Conservation Targets. PLOS ONE 7, e32529.

BUTCHART, S.H.M., WALPOLE, M., COLLEN, B., VAN STRIEN, A., SCHARLEMANN, J.P.W., ALMOND, R.E.A., BAILLIE, J.E.M., BOMHARD, B., BROWN, C., BRUNO, J., CARPENTER, K.E., CARR, G.M., CHANSON, J., CHENERY, A.M., CSIRKE, J., DAVIDSON, N.C., DENTENER, F., FOSTER, M., GALLI, A., GALLOWAY, J.N., GENOVESI, P., GREGORY, R.D., HOCKINGS, M., KAPOS, V., LAMARQUE, J.-F., LEVERINGTON, F., LOH, J., MCGEOCH, M.A., MCRAE, L., MINASYAN, A., MORCILLO, M.H., OLDFIELD, T.E.E., PAULY, D., QUADER, S., REVENGA, C., SAUER, J.R., SKOLNIK, B., SPEAR, D., STANWELL-SMITH, D., STUART, S.N., SYMES, A., TIERNEY, M., TYRRELL, T.D., VIÉ, J.-C., WATSON, R., 2010. Global Biodiversity: Indicators of Recent Declines. Science 328, 1164.

CAMPBELL, C.S., ADAMS, C.E., BEAN, C.W., PARSONS, K.J., 2017. Conservation Evo-Devo: Preserving Biodiversity by Understanding Its Origins. Trends in Ecology \& Evolution 32, 746-759.

CAMPOS-ARCEIZ, A., PRIMACK, R.B., MILLER-RUSHING, A.J., MARON, M., 2018. Striking underrepresentation of biodiversity-rich regions among editors of conservation journals. Biological Conservation 220, 330-333.

CAN, T., 20I3. Ormanın Kitabı. WWF-Türkiye, İstanbul.

CEBALLOS, G., EHRLICH, P.R., BARNOSKY, A.D., GARCÍA, A., PRINGLE, R.M., PALMER, T.M., 2015. Accelerated modern human-induced species losses: Entering the sixth mass extinction. Science Advances I, el 400253.

CEPF, 2019. Explore the Biodiversity Hotspots. Critical Ecosystem Partnership Fund, Arlington, USA. 
CHAPE, S., HARRISON, J., SPALDING, M., LYSENKO, I., 2005. Measuring the extent and effectiveness of protected areas as an indicator for meeting global biodiversity targets. Philosophical Transactions of the Royal Society B: Biological Sciences 360, 443-455.

CHAPRON, G., LEVREL, H., MEINARD, Y., COURCHAMP, F., 2018. Satire for Conservation in the 21 st Century. Trends in Ecology \& Evolution 33, 478-480.

COSTELLO, M.J., BALLANTINE, B., 20I5. Biodiversity conservation should focus on no-take Marine Reserves: 94\% of Marine Protected Areas allow fishing. Trends in Ecology \& Evolution 30, 507-509.

COŞKUN, A.A., 2005. An evaluation of the environmental impact assessment system in Turkey. International Journal of Environment Sustainable Development, 4, 47-66.

CULLEN, R., FAIRBURN, G.A., HUGHEY, K.F.D., $200 \mathrm{I}$. Measuring the productivity of threatened-species programs. Ecological Economics 39, 53-66.

ÇAĞATAY, A., TERZIOĞLU, E., EKMEN, İ., ERDOĞAN, E., 20I3. Biyolojik Çeşitliliği İzleme ve Değerlendirme Raporu 2012, Ankara, p. 103.

DE GROOT, R.S., WILSON, M.A., BOUMANS, R.M., 2002. A typology for the classification, description and valuation of ecosystem functions, goods and services. Ecological Economics 4I, 393-408.

DE WITT, M., POPE, J., RETIEF, F., BOND, A., MORRISONSAUNDERS, A., STEENKAMP, C., 2019. Biodiversity offsets in EIA: Getting the timing right. Environmental Impact Assessment Review 75, I-I2.

DEMIRAYAK, F., 2002. Biyolojik Çeşitlilik-Doğa Koruma Ve Sürdürülebilir Kalkınma, p. 30.

DoğaDerneği, Turkey’s Biodiversity. https://www.dogadernegi. org/en/turkeys-biodiversity/ Accessed in: January I th 2019.'

DUDLEY, N., MULONGOY, K., COHEN, S., STOLTON, S. BARBER, C., GIDDA, S., 2005. Etkin korunan alan sistemlerine doğru: Biyolojik Çeşitlilik Sözleşmesi Korunan Alanlar İş Programı Uygulama Kılavuzu. WWF-Türkiye, İstanbul.

EICHNER, T., PETHIG, R., 20I8. Self-enforcing Biodiversity Agreements with Financial Support from North to South. Ecological Economics I53, 43-55

ERDÖNMEZ, C., ATMIŞ, A., ÖZDEN, S., 20I0. Türkiye'de ormancılık politikası, in: Aytuğ, A., Abdi, E. (Eds.), Ormancilık Politikası. Türkiye Ormancılar Derneği, pp. I02-I46.

ERGÜNER, Y., KUMAR, J., HOFFMAN, F.M., DALFES, H.N., HARGROVE, W.W., 20I8. Mapping ecoregions under climate change: a case study from the biological 'crossroads' of three continents, Turkey. Landscape Ecology, 34, 35-50.

ERIK, S., TARIKAHYA, B., 2004. Türkiye Florası Üzerine. Kebikeç I7, I39-163.
ERTÜRK, E., Sürdürülebilir Kalkınma Bir Başarı Öyküsü: "Camili Biyosfer Rezervi”. UNESCO. 2019. http://www. unesco.org.tr/Content_Files/Content/Sektor/Doga_ Bilimleri/skkboc.PDF Accessed in: January I I th

ERVIN, J., SEKHRAN, N., DINU, A., GIDDA, S., VERGEICHIK, M., MEE, J., 20I0. Protected Areas for the 2 I st Century: Lessons from UNDP/GEF's Portfolio. UNDP, p. 132.

FAO, 2010. Global forest resources assessment, Country Report-Turkey. Food and Agriculture Organization of the United Nations, Rome, p. 62.

GANNON, P., SEYOUM-EDJIGU, E., COOPER, D., SANDWITH, T., DE SOUZA DIAS, B.F., PALMER, C.P., LANG, B., ERVIN, J., GIDDA, S., 20I7. Status and prospects for achieving Aichi biodiversity Target II: implications of national commitments and priority actions. Parks, I3.

GASTON, K.J., JACKSON, S.F., CANTÚ-SALAZAR, L., CRUZ-PIÑÓN, G., 2008. The Ecological Performance of Protected Areas. Annual Review of Ecology, Evolution, and Systematics 39, 93-113.

GDF, 20I5. Türkiye Orman Varlığı Ankara, p. 36.

GDF, 20I6. Orman Genel Müdürlüğü Stratejik Planı (20I7202I), Ankara, p. 92.

GDF, 2018. Orman Genel Müdürlüğü Stratejik Plan 20I9-2023, Ankara, p. 82.

GDNCNP, 2013. Status Report on Nature Conservation (20022013), Ankara, p. 39.

GDNCNP, 2016. Tabiati Koruma Durum Raporu (2014-20I5) Ankara.

GDNCNP, Korunan Alanlar. http://www.milliparklar.gov.tr/ Korunan- Alanlar/ Accessed in: January 5th 2019.

GIBBONS, P., LINDENMAYER, D.B., 2007. Offsets for land clearing: No net loss or the tail wagging the dog? Ecological Management \& Restoration 8, 26-31.

GORDON, J.E., 2006. The role of science in NGO mediated conservation: insights from a biodiversity hotspot in Mexico. Environmental Science \& Policy 9, 547-554.

GÖKYIĞIT, A., 2013. Türkiye'nin Biyolojik Zenginliği ve Korunması. Ali Nihat Gökyiğit Vakfı, İstanbul.

GRAY, C.L., HILL, S.L.L., NEWBOLD, T., HUDSON, L.N., BÖRGER, L., CONTU, S., HOSKINS, A.J., FERRIER, S., PURVIS, A., SCHARLEMANN, J.P.W., 20 I6. Local biodiversity is higher inside than outside terrestrial protected areas worldwide. Nature Communications 7, 12306.

GROSS, M., 2012. Turkey's biodiversity at the crossroads. Current Biology 22, R503-R505.

GROVES, C.R., GAME, E.T., 2016. Conservation Planning: Informed Decisions for a Healthier Planet. Roberts and Company Publishers, Greenwood Village, Colorado. 
GUADILLA-SÁEZ, S., PARDO-DE-SANTAYANA, M., REYESGARCÍA, V., SVENNING, J.-C., 2019. Biodiversity conservation effectiveness provided by a protection status in temperate forest commons of north Spain. Forest Ecology and Management 433, 656-666.

GUSTAFSSON, K.M., 2013. Environmental discourses and biodiversity: the construction of a storyline in understanding and managing an environmental issue AU - Gustafsson, Karin M. Journal of Integrative Environmental Sciences 10, 39-54.

GÜNER, I., 20I6. Resimli Türkiye Florası - Dev gibi bir proje.

HACIOĞLU, S., DINCER, E., ISLER, C.T., KARAPINAR, Z., ATASEVEN, V.S., ÖZKUL, A., ERGUNAY, K., 2017. A snapshot avian surveillance reveals West Nile virus and evidence of wild birds participating in Toscana virus circulation. Vector-Borne Zoonotic Diseases 17, 698-708.

HAINES-YOUNG, R., 2009. Land use and biodiversity relationships. Land use policy $26, \mathrm{SI} 78-\mathrm{SI} 86$.

HANSEN, M.C., POTAPOV, P.V., MOORE, R., HANCHER, M., TURUBANOVA, S.A., TYUKAVINA, A., THAU, D., STEHMAN, S.V., GOETZ, S.J., LOVELAND, T.R., KOMMAREDDY, A., EGOROV, A., CHINI, L., JUSTICE, C.O., TOWNSHEND, J.R.G., 20I3. High-Resolution Global Maps of 2 Ist-Century Forest Cover Change. Science 342, 850.

HARLAN, J.R., I95I. Anatomy of Gene Centers. The American Naturalist 85, 97-103.

HASSAN, R., SCHOLES, R., ASH, N., 2005. Ecosystems and human well-being: current state and trends, vol I. Findings of the condition and trends working group of the Millennium Ecosystem Assessment. Washington, DC: Island Press.

HOFFMANN, M., BELANT, J.L., CHANSON, J.S., COX, N.A., LAMOREUX, J., RODRIGUES, A.S., SCHIPPER, J., STUART, S.N., 20II. The changing fates of the world's mammals. Philosophical Transactions of the Royal Society B: Biological Sciences 366, 2598-26I0.

HUANG, C.-W., MCDONALD, R.I., SETO, K.C., 20I8. The importance of land governance for biodiversity conservation in an era of global urban expansion. Landscape and Urban Planning 173, 44-50.

JACOBS, S., DENDONCKER, N., KEUNE, H., 2013 Ecosystem services: global issues, local practices. Elsevier.

JUFFE-BIGNOLI, D., BURGESS, N.D., BINGHAM, H., BELLE, E., DE LIMA, M., DEGUIGNET, M., BERTZKY, B., MILAM, A., MARTINEZ-LOPEZ, J., LEWIS, E., 20I4. Protected planet report 2014. UNEP-WCMC, Cambridge, UK, p. 69.

KARAÇETIN, E., WELCH, H., 20I I. Red book of butterflies in Turkey. Nature Conservation Center, Ankara.

KARAGÖZ, A., 2003. Plant Genetic Resources Conservation in Turkey, 598 ed. International Society for Horticultural Science (ISHS), Leuven, Belgium, pp. 17-25.
KARAMAN, C., AKTAÇ, N., 2013. Descriptions of four new species of Camponotus Mayr (Hymenoptera: Formicidae), with a key for the worker caste of the Camponotus of Turkey. Journal of the Kansas Entomological Society 86, 36-57.

KARAMAN, C., KIRAN, K., AKSOY, V., CAMLITEPE, Y., 2015. First Record of The South European Rare Parasitic Ant Species Camponotus universitatis Forel (Hymenoptera, Formicidae) in Asia. Journal of the Entomological Research Society 17, 45-49.

KEENAN, R.J., REAMS, G.A., ACHARD, F., DE FREITAS, J.V., GRAINGER, A., LINDQUIST, E., 20I5. Dynamics of global forest area: Results from the FAO Global Forest Resources Assessment 2015. Forest Ecology and Management 352, 9-20.

KIRAN, K., KARAMAN, C., 20I2. First annotated checklist of the ant fauna of Turkey (Hymenoptera: Formicidae). Zootaxa 3548, I-38.

LU, M., QU, Y., 20I8. Biodiversity conservation development based on Systematic Conservation Planning in urban areas. Energy Procedia 153, 484-488.

MARON, M., DUNN, P.K., MCALPINE, C.A., APAN, A., 2010. Can offsets really compensate for habitat removal? The case of the endangered red-tailed black-cockatoo. Journal of Applied Ecology 47, 348-355.

MATHEWS, F., 2016. From biodiversity-based conservation to an ethic of bio-proportionality. Biological Conservation 200, | 140-| 48.

MEA, 2005. Ecosystems and Human Well-being: Biodiversity Synthesis. World Resources Institute, Washington, DC., p. 85.

MÉDAIL, F., BAUMEL, A., 2018. Using phylogeography to define conservation priorities: The case of narrow endemic plants in the Mediterranean Basin hotspot. Biological Conservation 224, 258-266.

MEF, 2009. UN Convention of Biological Diversity Fourth National Report of Turkey, Ankara, p. 75.

MFWA, 2014. UN Convention on Biological Diversity Fifth National Report of Turkey, Ankara, p. 47.

MICHEL, A.K., PRESCHER, A.-K., SEIDLING, W., FERRETTI, M., 2018. ICP Forests A policy-relevant infrastructure for long-term, large-scale assessment and monitoring of forest ecosystems, in: Michel, A.K., Seidling, W. (Eds.), ICP Forests Brief \# I, Mertinkat, Eberswalde, Germany, p. 6.

MILLER, G.T., SPOOLMAN, S., 20I5. Environmental Science. Cengage Learning.

MITTERMEIER, R., GIL, P., HOFFMANN, M., PILGRIM, J., BROOKS, T., MITTERMEIER, C., LAMOREUX, J., DA FONSECA, G., 2005. Hotspots Revisited: Earth's Biologically Richest and Most Endangered Terrestrial Ecoregions, 2 ed. Conservation International. 
MOAF, 20।9. Tarım ve Orman Bakanlı̆̆ı GeoData Uygulaması. Tarım ve Orman Bakanlı̆̆ı, Ankara.

MOE, 200I. The National Strategy and Action Plan for Biodiversity in Turkey. Ministry of Environment, Ankara, p. 37.

MOEF, 2007. UN Convention of Biological Diversity Third National Report of Turkey, Ankara, p. 144.

MOEF, 2008. The National Biological Diversity Strategy and Action Plan 2007 V2, Ankara, p. 176.

MOEF, 20I I. Ulusal Biyolojik Çeşitlilik İzleme Raporu - 20I I, Ankara, p. 36.

MOEU, 2019. Türkiye'deki Korunan Alan Statüleri ve Alansal Dağııım. Ministry of Environment and Urbanization Ankara.

MOF, 1998. First National Report of Turkey for UN Convention on Biological Diversity, Ankara, p. 38.

MOF, 200I. The National Strategy and Action Plan for Biodiversity in Turkey. Ministry of Forestry, Ankara, p. 37.

MYERS, N., 1988. Threatened biotas: "Hot spots" in tropical forests. Environmentalist 8, 187-208.

MYERS, N., MITTERMEIER, R.A., MITTERMEIER, C.G., DA FONSECA, G.A., KENT, J., 2000. Biodiversity hotspots for conservation priorities. Nature 403, 853.

NICHOLSON, E., FULTON, E.A., BROOKS, T.M., BLANCHARD, R., LEADLEY, P., METZGER, J.P., MOKANY, K., STEVENSON, S., WINTLE, B.A., WOOLLEY, S.N.C., BARNES, M., WATSON, J.E.M., FERRIER, S., 2019. Scenarios and Models to Support Global Conservation Targets. Trends in Ecology \& Evolution 34, 57-68.

PALACÍN, C., ALONSO, J.C., 20I8. Failure of EU Biodiversity Strategy in Mediterranean farmland protected areas. Journal for Nature Conservation 42, 62-66.

PIAGGIO, A.J., SEGELBACHER, G., SEDDON, P.J., ALPHEY, L., BENNETT, E.L., CARLSON, R.H., FRIEDMAN, R.M., KANAVY, D., PHELAN, R., REDFORD, K.H., ROSALES, M., SLOBODIAN, L., WHEELER, K., 2017. Is It Time for Synthetic Biodiversity Conservation? Trends in Ecology \& Evolution 32, 97-107.

PIMENTEL, D., WILSON, C., MCCULLUM, C., HUANG, R., DWEN, P., FLACK, J., TRAN, Q., SALTMAN, T., CLIFF, B., 1997. Economic and environmental benefits of biodiversity. BioScience, 47, 747-757.

PROTECTEDPLANET, 2019. Protected area coverage per country/territory by UN Environment Regions.

RICE, R.E., 2018. Market-Based Approaches to Biodiversity Conservation: An Overview of Experience in Developed and Developing Countries. Encyclopedia of the Anthropocene 3, 423-428.
RIPPLE, W.J., WOLF, C., NEWSOME, T.M., GALETTI, M., ALAMGIR, M., CRIST, E., MAHMOUD, M.I., LAURANCE, W.F., 20I7. World scientists' warning to humanity: A second notice. BioScience 67, 1026-1028.

RODRIGUES, A.S.L., DA FONSECA, G.A.B., AKÇAKAYA, H.R., SCHIPPER, J., CHANSON, J.S., PILGRIM, J.D., GASTON, K.J., UNDERHILL, L.G., FISHPOOL, L.D.C., BOITANI, L., WATTS, M.E.J., HOFFMANN, M., BAKARR, M.I., MARQUET, P.A., PRESSEY, R.L., WALLER, R.W., ANDELMAN, S.J., STUART, S.N., BROOKS, T.M., SECHREST, W., YAN, X., 2004. Global Gap Analysis: Priority Regions for Expanding the Global Protected-Area Network. BioScience 54, I092-I I00.

ROUNSEVELL, M., FISHER, M., BOERAEVE, F., JACOBS, S., LIEKENS, I., MARQUES, A., MOLNÁR, Z., OSUCHOVA, J., SHKARUBA, A., WHITTINGHAM, M., 2018. The Regional Assessment Report on Biodiversity and Ecosystem Services for Europe and Central Asia: Chapter I Setting the Scene. IPBES (Intergovernmental Platform for Biodiversity and Ecosystem Services).

SALA, O.E., STUART CHAPIN, F., III, ARMESTO, J.J., BERLOW, E., BLOOMFIELD, J., DIRZO, R., HUBER-SANWALD, E., HUENNEKE, L.F., JACKSON, R.B., KINZIG, A., LEEMANS, R., LODGE, D.M., MOONEY, H.A., OESTERHELD, M.N., POFF, N.L., SYKES, M.T., WALKER, B.H., WALKER, M., WALL, D.H., 2000. Global Biodiversity Scenarios for the Year 2100 . Science 287, 1770.

SANDERSON, E.W., JAITEH, M., LEVY, M.A., REDFORD, K.H., WANNEBO, A.V., WOOLMER, G., 2002. The Human Footprint and the Last of the Wild: The human footprint is a global map of human influence on the land surface, which suggests that human beings are stewards of nature, whether we like it or not. BioScience 52, 891-904.

SATAR, I., GÜNEŞ, G., 20I4. Türklye'nin Biyolojilk Çeşitlilik Sıcak Noktaları. Tabiat ve İnsan 48, 22-34.

SAYGILI, R., Türkiye Orman Haritası. 2016 http://cografyaharita. com/haritalarim/2dturkiye-orman-haritasi.png Accessed in: January 16th 2019.'

SCHMITT, C.B., BURGESS, N.D., COAD, L., BELOKUROV, A., BESANCON, C., BOISROBERT, L., CAMPBELL, A., FISH, L., GLIDDON, D., HUMPHRIES, K., KAPOS, V., LOUCKS, C., LYSENKO, I., MILES, L., MILLS, C., MINNEMEYER, S., PISTORIUS, T., RAVILIOUS, C., STEININGER, M., WINKEL, G., 2009. Global analysis of the protection status of the world's forests. Biological Conservation I42, 2122-2130.

SCHOLES, R.J., BIGGS, R., 2005. A biodiversity intactness index. Nature 434, 45.

STEFFEN, W., RICHARDSON, K., ROCKSTRÖM, J., CORNELL, S.E., FETZER, I., BENNETT, E.M., BIGGS, R., CARPENTER, S.R., DE VRIES, W., DE WIT, C.A., FOLKE, C., GERTEN, D., HEINKE, J., MACE, G.M., PERSSON, L.M., RAMANATHAN, V., REYERS, B., SÖRLIN, S., 2015. Planetary boundaries: Guiding human development on a changing planet. Science 347, 1259855. 
STERLING, E.J., BETLEY, E., SIGOUIN, A., GOMEZ, A., TOOMEY, A., CULLMAN, G., MALONE, C., PEKOR, A., ARENGO, F., BLAIR, M., FILARDI, C., LANDRIGAN, K., PORZECANSKI, A.L., 20I7. Assessing the evidence for stakeholder engagement in biodiversity conservation. Biological Conservation 209, 159-171.

ŞEKERCIOĞLU, Ç.H., ANDERSON, S., AKÇAY, E., BILGIN, R. CAN, Ö.E., SEMIZ, G., TAVŞANOĞLU, Ç., YOKEŞ, M.B., SOYUMERT, A., IPEKDAL, K., SAĞLAM, I..K., YÜCEL, M., NÜZHET DALFES, H., 20II. Turkey's globally important biodiversity in crisis. Biological Conservation I44, 2752-2769.

ŞENKUL, Ç., DOĞAN, U., 20I3. Vegetation and climate of Anatolia and adjacent regions during the Last Glacial period. Quaternary International 302, I I0-122.

ŞENKUL, Ç., KAYA, S., 20I7. Türkiye Endemik Bitkilerinin Coğrafi Dağılışı. Türk Coğrafya Dergisi 69, I09-I20.

ŞIMŞEK, E., 20I4. Protection of Biodiversity in Turkey. Public and Private International Law Bulletin 34, 73-92.

TAN, A., 20I0. Türkiye Gıda ve Tarım Bitki Genetik Kaynaklarının Durumu Gıda ve Tarım için Bitki Kaynaklarının Muhafazası ve Sürdürülebilir Kullanımına Illişkin TÜRKIYE İkinci Ülke Raporu. Ege tarımsal Araştırma Enstitüsü, Menemen, İzmir, p. 50.

TERZIOĞLU, S., BILGILI, E., KARAKÖSE, M., 20I2. Forests of Turkey. General Directorate of Forestry, Ankara.

TERZIOĞLU, S., BILGILI, E., KARAKÖSE, M., 20I5. Forests of Turkey. T.C. Orman ve Su İşleri Bakanlı̆̆ı, Orman Genel Müdürlüğü, Ankara.

THOMPSON, I., MACKEY, B., MCNULTY, S., MOSSELER, A., 2009. Forest Resilience, Biodiversity, and Climate Change. A synthesis of the biodiversity/resilience/stability relationship in forest ecosystems., Technical Series. Secretariat of the Convention on Biological Diversity, Montreal, p. 67.

TISDELL, C., 20I I. Biodiversity conservation, loss of natural capital and interest rates. Ecological Economics 70, 25 I I-25I5.

TITTENSOR, D.P., WALPOLE, M., HILL, S.L.L., BOYCE, D.G., BRITTEN, G.L., BURGESS, N.D., BUTCHART, S.H.M., LEADLEY, P.W., REGAN, E.C., ALKEMADE, R., BAUMUNG, R., BELLARD, C., BOUWMAN, L., BOWLES-NEWARK, N.J., CHENERY, A.M., CHEUNG, W.W.L., CHRISTENSEN, V., COOPER, H.D., CROWTHER, A.R., DIXON, M.J.R., GALLI, A., GAVEAU, V., GREGORY, R.D., GUTIERREZ, N.L., HIRSCH, T.L., HÖFT, R., JANUCHOWSKI-HARTLEY, S.R., KARMANN, M., KRUG, C.B., LEVERINGTON, F.., LOH, J., LOJENGA, R.K., MALSCH, K., MARQUES, A., MORGAN, D.H.W., MUMBY, P.J., NEWBOLD, T., NOONANMOONEY, K., PAGAD, S.N., PARKS, B.C., PEREIRA, H.M., ROBERTSON, T., RONDININI, C., SANTINI, L., SCHARLEMANN, J.P.W., SCHINDLER, S., SUMAILA, U.R., TEH, L.S.L., VAN KOLCK, J., VISCONTI, P., YE, Y., 20I4. A mid-term analysis of progress toward international biodiversity targets. Science 346, 241.
TOLUNAY, D., ÖZTÜRK, S., GÜRLEVIK, N., KARAKAŞ, A., AKKAŞ, M.E., ADIGÜZEL, U., TAŞDEMIR, C., AYTUR, F., 2012. Health State of Forests in Turkey (2008 - 20I2), Ankara, p. 88.

UNEP-WCMC, IUCN, 20I6. Protected planet report 20I6. UNEP World Conservation Monitoring Centre, Cambridge, UK, Gland, Switzerland, p. 73.

UNEP-WCMC, IUCN, 2017. Protected Planet: The World Database on Protected Areas (WDPA). www. protectedplanet.net, Cambridge, UK.

UNEP-WCMC, IUCN, NGS, 2018. Protected Planet Report 20I8, Cambridge, UK

Gland, Switzerland Washington, D.C., USA, p. 70.

UNEP-WCMC, IUCN, NGS, 2018. Protected Planet Report 2018, Cambridge, UK Gland, Switzerland, Washington, D.C., USA, p. 70

URSAVAŞ, S., IŞIN, Z., 20I8. New records of Bryum gemmiferum and Atrichum crispum for Turkey. Plant Biosystems-An International Journal Dealing with all Aspects of Plant Biology, I-5.

ÜNAL, H.E., BIRBEN, Ü., BOLAT, F., 2019. Rural population mobility, deforestation, and urbanization: case of Turkey. Environmental Monitoring and Assessment 191, 21.

ÜSTÜNDAĞ, M., 20I5. Biyolojik Çeşitlilik. ÜSTÜNDAĞ, M., Biyolojik Çeşitlilik. 2015 http://www.fenokulu.net/yeni/ Fen-Konulari/Konu/BiyolojikCesitlilik-Cevre-sorunlari-veetkileri-Konu-Anlatimi_456.html Accessed in: January 7th 2019.'

VAN SWAAY, C., CUTTELOD, A., COLLINS, S., MAES, D., MUNGUIRA, M.L., ŠAŠIĆ, M., SETTELE, J., VEROVNIK, R., VERSTRAEL, T., WARREN, M., 20I0. European red list of butterflies. Publications office of the European Union, Luxembourg.

VELASCO, D., GARCÍA-LLORENTE, M., ALONSO, B., DOLERA, A., PALOMO, I., INIESTA-ARANDIA, I., MARTÍN-LÓPEZ, B., 20I5. Biodiversity conservation research challenges in the 2Ist century: A review of publishing trends in 2000 and $201 \mathrm{I}$. Environmental Science Policy, 54, 90-96.

VENTER, O., SANDERSON, E.W., MAGRACH, A., ALLAN, J.R., BEHER, J., JONES, K.R., POSSINGHAM, H.P., LAURANCE, W.F., WOOD, P., FEKETE, B.M., LEVY, M.A., WATSON, J.E.M., 2016. Sixteen years of change in the global terrestrial human footprint and implications for biodiversity conservation. Nature Communications 7, I 2558.

Vitousek, P.M., Mooney, H.A., Lubchenco, J., Melillo, J.M., 1997. Human Domination of Earth's Ecosystems. Science 277, 494.

WETZEL, F.T., BINGHAM, H.C., GROOM, Q., HAASE, P., KÕLJALG, U., KUHLMANN, M., MARTIN, C.S., PENEV, L., ROBERTSON, T., SAARENMAA, H., SCHMELLER, D.S., STOLL, S., TONKIN, J.D., HÄUSER, C.L., 2018. Unlocking biodiversity data: Prioritization and filling the gaps in biodiversity observation data in Europe. Biological Conservation 221, 78-85. 
WOOD, P.M., 1997. Biodiversity as the source of biological resources: a new look at biodiversity values. Environmental Values 6, 25I-268.

WORLDBANK, 200I. Turkey Forestry Sector Review. Environmentally and Socially Sustainable Development Unit Europe and Central Asia Region, Washington, DC p. 8I.

WORM, B., DUFFY, J.E.J.T.I.E. 2003. Biodiversity, productivity and stability in real food webs. Trends in Ecology \& Evolution 18, 628-632.
WWF, 2015. 10 Species that Hug Trees.

YILDIRIM, H.T., YURDAKUL EROL, S., 20I2. Korunan alanlar, ekolojik işlevleri ve geleceğe yönelik tahminler. Biyoloji Bilimleri Araştırma Dergisi, I0I-I09.

ZEYDANLI, U.S., TURAK, A.S., BALKIZ, Ö., ÖZÜT, D., ERTÜRK, A., WELCH, H., KARAÇETIN, E., AMBARLI, D., DURMUŞ, M., CAN BILGIN, C., 20I2. Identification of Prime Butterfly Areas in Turkey using systematic conservation planning: Challenges and opportunities. Biological Conservation 150, 86-93. 